\title{
Functional results and complications of Mersilene mesh use for frontalis suspension ptosis surgery
}

\author{
P Mehta, P Patel, J M Olver
}

Br J Ophthalmol 2004;88:361-364. doi: 10.1136/bjo.2002.009951

\begin{abstract}
Aims: To assess the functional results and complications of Mersilene (polyester) mesh frontalis sling suspension to correct poor levator function ptosis.

Methods: Retrospective case series. 32 eyelids of 20 patients (12 children and eight adults).

Results: Follow up 1-69 months (mean 32). Children: eight patients had bilateral and four unilateral surgery $(20$ eyelids). Good long term functional results were achieved in $73 \%(8 / 11$ children) and $77 \%(14 / 18)$ eyelids. Two children had early postoperative wound infection requiring removal of mesh in one; the other was lost to follow up following medical treatment. Adults: four patients had bilateral and four unilateral surgery (12 eyelids). Good long term functional results were achieved in $75 \%$ (6/8 patients, $9 / 12$ eyelids). One postoperative wound infection and one mesh exposure were treated definitively by surgical excision of mesh.

Conclusion: Mersilene mesh provides good functional results but up to $20 \%$ of patients have early soft tissue complications. Other materials such as monofilament suture or autogenous fascia lata should be considered.
\end{abstract}

$\mathrm{F}$ rontalis sling surgery (brow suspension) is the surgery of choice for poor levator function ptosis $(<5 \mathrm{~mm})^{1-3}$ and autogenous fascia lata (AFL) is the gold standard with which other materials should be compared. ${ }^{4}$ Surgeons and patients sometimes prefer non-autogenous material, ${ }^{5-27}$ because surgery can be done under local anaesthesia in adult patients and a second incision can be avoided. It is also preferred when AFL is not available as in very young children with short legs. ${ }^{4} 1516$

The use of Mersilene mesh as an alternative material in frontalis suspension surgery was described by Downes and Collin in $1989^{5}$ and others ${ }^{6-14}$ have discussed its use. Mersilene is a sterile wrapped polyester fibre. It has good tensile strength and forms a permanent scaffold for fibrovascular tissue ingrowth, and hence good long term functional results. ${ }^{5-14}$

Materials for frontalis suspension should have good long term results with a low complication rate. Human sclera, banked fascia lata, expanded poly(tetrafluoroethylene) (ePTFE or Gore-Tex), braided polyester, monofilaments, and silicone rod have also been used..$^{15-28}$

Important results include eyelid height, skin crease depth, and eyelid contour. The aim of this study was to determine the long term results and complications of Mersilene mesh in frontalis suspension surgery for the correction of poor levator function ptosis.

\section{MATERIALS AND METHODS}

Mersilene mesh for frontalis suspension was used in 20 patients (32 eyelids) with poor levator function ptosis (0-
$5 \mathrm{~mm}$ ). There were 12 children (20 eyelids) and eight adults ( 12 eyelids). Eight patients had unilateral (four adults, four children) and 12 had bilateral surgery. Four adult patients had undergone previous ptosis surgery. In three of these the details were unavailable; one had undergone an anterior levator resection.

\section{Surgical procedure}

A modified Fox pentagon ${ }^{3}$ was used with five stab incisions, two in the eyelid and three above the eyebrow. The sterile Mersilene mesh sheet was cut into strips 5-7 mm wide, $150 \mathrm{~mm}$ long, along the long axis of the oval mesh pore. The strips were soaked in antibiotic solution immediately before use (gentamicin or chloromycetin). A Wright's fascial needle was used to insert the strip deep to orbicularis and frontalis muscles. The eyelid stab incisions were closed with 8.0 Vicryl. The two ends of the mesh at the apical brow incision were secured together by a half knot and 6.0 Vicryl suture. This gave a small sized "knot" buried deep to frontalis muscle.

The brow incisions were closed in two layers using 6.0 Vicryl subcutaneous and interrupted 8.0 Vicryl (child) or 6.0 Novafil (adult) to skin. Oral broad spectrum antibiotics (erythromycin in children and Augmentin in adults) were prescribed for all patients for 1 week. Topical antibiotics and lubricants were routinely used for the first week and then as required.

\section{RESULTS}

The records for all patients were retrieved. Mean follow up was 32 months. One child (case 1) whose family moved to another part of the country had a follow up of only 1 month.

A consultant oculoplastic surgeon operated on 18/20 patients and an oculoplastics fellow $2 / 20$.

\section{Long term functional results (table 1)}

All eyelids had improvement in the lid height with a good deep skin crease. Height was maintained at 2 years in $73 \%$ (8/ $11)$ of children and $75 \%(6 / 8)$ of adults. This represented good long term functional results in $77 \%$ (14/18) of eyelids in children and $75 \%(9 / 12)$ of eyelids in adults. Two children with unilateral ptosis had a poor functional result from not using their frontalis muscle and one a poor skin crease. There were no overcorrections.

Two of 20 patients (four of 32 eyelids, 12.5\%) required further surgery for recurrent ptosis following Mersilene excision (cases 2 and 3 ).

\section{Soft tissue complications}

Four patients (two bilateral and two unilateral surgery) developed soft tissue complications 1-4 weeks after surgery.

Case 1

This was a 4 year old girl with bilateral congenital dystrophic ptosis. Two weeks after surgery a small raised red lesion was seen on the medial aspect of the left brow, a presumed 
Table 1 Results of frontalis suspension surgery using Mersilene mesh

\begin{tabular}{|c|c|}
\hline Total number of patients & 20 (14 male, 6 female) \\
\hline Age range & $2-78$ years \\
\hline Total number of eyelids & 32 \\
\hline \multicolumn{2}{|l|}{ Diagnosis } \\
\hline Congenital dystrophic ptosis & 12 \\
\hline Blepharophimosis & 3 \\
\hline Congenital third nerve palsy & 1 \\
\hline CPEO & 1 \\
\hline Oculopharyngeal muscular dystrophy & 1 \\
\hline Myotonic dystrophy & 1 \\
\hline Ocular myopathy & 1 \\
\hline \multicolumn{2}{|l|}{ Preoperative findings } \\
\hline \multicolumn{2}{|l|}{ MRD (mm) } \\
\hline Mean & 0 \\
\hline Range & $0-1$ \\
\hline Levator function & absent to poor $(0-5 \mathrm{~mm})$ \\
\hline \multicolumn{2}{|l|}{ Postoperative findings } \\
\hline Minimum 24 months after surgery & $\mathrm{n}=17$ (26 eyelids) \\
\hline \multicolumn{2}{|l|}{ MRD $(\mathrm{mm})$} \\
\hline Mean & +3.4 \\
\hline Range & +2.5 to +4.0 \\
\hline \multicolumn{2}{|l|}{ Follow up (months) } \\
\hline Mean & 32 \\
\hline Median & 36 \\
\hline Range & $1-69$ \\
\hline $\begin{array}{l}\text { Good skin crease (minimum follow up } \\
12 \text { months after surgery) }\end{array}$ & $26 / 31$ eyelids \\
\hline Complications & \\
\hline Lagophthalmos-initial marked & 5 \\
\hline Temporary corneal exposure & 1 \\
\hline Infection/granuloma & 3 \\
\hline Exposure of mesh & 1 \\
\hline
\end{tabular}

CPEO = chronic progressive external ophthalmoplegia; $M R D=$ upper margin reflex distance.

forehead wound infection. Following a further course of systemic antibiotics she was lost to further follow up as her family had moved out of the region. Details of her subsequent outcome were not available despite several attempts to trace her.

\section{Case 2}

This was a 6 year old boy with bilateral congenital dystrophic ptosis. Ten days after surgery he developed inflamed red lumps at the site of the eyelid and brow stab incisions. He did not reattend until 3 weeks after surgery by which time he had micro abscesses (fig 1A). Following systemic antibiotics the forehead and eyelid abscesses were excised along with a length of infected Mersilene mesh. There was no bacteriological growth. He required maximum levator resection for recurrent ptosis.

\section{Case 3}

This was a 30 year old man with congenital dystrophic ptosis. One week after surgery he developed bilateral eyelid wound infections. He was given a further course of systemic antibiotics but it failed to settle and the mesh was excised $2 \frac{1}{2}$ weeks later. Four months later he required AFL frontalis suspension for recurrent ptosis.

\section{Case 4}

This was a 23 year old man with a congenital third nerve palsy. Four weeks after surgery exposed mesh was noted at the brow incision site (fig 1B). He underwent excision of the stab incision area and underlying mesh. Postoperative his eyelid height was adequately maintained without further ptosis surgery.

\section{DISCUSSION}

This case series confirms the good long term results of Mersilene mesh when used for frontalis suspension $(76 \%$
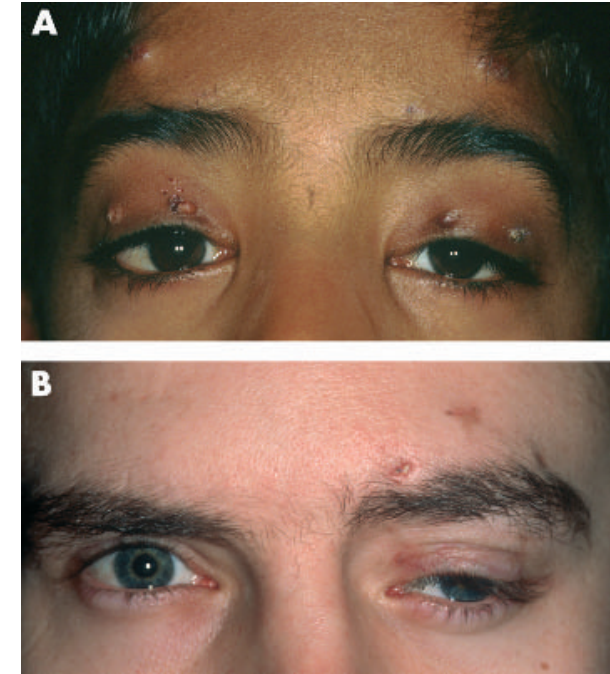

Figure 1 (A) Bilateral postoperative eyelid and forehead wound infection in 6 year old boy (case 2). (B) Forehead Mersilene mesh exposure in a 23 year old man with congenital third nerve palsy (case 4).

eyelids), but it was not as good as AFL (92\%). ${ }^{4}$ Soft tissue complications such as extrusion, granuloma, and infection unfortunately do occur. Surgeons should be aware of the risks of this material, especially as removal of the mesh may result in gradual recurrence of the ptosis. Extrusion of Mersilene mesh used as an upper eyelid spacer has also been reported in $20 \%$ cases. $^{29}$

AFL is considered the best frontalis suspensory material, as it is not degraded and is believed to allow fibrovascular tissue ingrowth leading to biointegration without significant inflammation. AFL has good long term functional results with maintenance of lid height and well formed skin crease. There are only occasional reports of postoperative wound infection..$^{43}$ Stored fascia lata has a higher rate of late ptosis recurrence. ${ }^{28}$

There is a wide choice of non-autogenous materials for frontalis suspension ${ }^{15-28}$ (table 2).

Monofilament synthetic materials-for example, Prolene and silicone rod, are not incorporated into tissues and their functional results are often less satisfactory than autogenous fascia lata, with ptosis recurrence and loss of skin crease, ${ }^{18} 2023-2428$ but they have low rates of infection and exposure/extrusion and are easily removed if the eyelid is too high.

Mersilene mesh has been promoted as an alternative to autogenous fascia lata because it acts as a scaffold for fibrovascular ingrowth and becomes integrated with tissue. ${ }^{611}{ }^{28-30}$ Initial results with Mersilene mesh were very encouraging. ${ }^{5-6}$ It avoids the need for a second surgical site and has a good long term effect. Reported complications of Mersilene and of Gore-Tex frontalis suspension include extrusion, granuloma and infection ${ }^{8-14} 192829$ (table 3).

Surprisingly, El-Toukhy ${ }^{13}$ had no complications in 46 eyelids. This may be attributed to their surgical modification where instead of eyelid stab incisions, there is a full eyelid crease incision and the Mersilene is sutured to the anterior surface of the tarsus. This ensures deep placement of the mesh within the eyelid, reducing the risk of exposure and infection. However, they have may have ignored the presence of small resolvable granulomas/low grade infection.

Meticulous wound closure with well buried mesh should reduce complications. ${ }^{8}$ Low grade infection may occur along the mesh from either the eyelid or forehead incisions, 
Table 2 Complications of frontalis suspension surgery with non-autogenous materials and autogenous fascia lata

\begin{tabular}{|c|c|c|c|c|c|}
\hline Author, year & Material used & No of patients & No of eyelids & $\begin{array}{l}\text { Mean follow up } \\
\text { (months) }\end{array}$ & Complications (infection/extrusion/granuloma) \\
\hline \multicolumn{6}{|l|}{ Silicone } \\
\hline Carter, $1997^{22}$ & Silicone rod & 35 & 61 & 22 & $\begin{array}{l}\text { Extrusion, } 3 \\
\text { Recurrence, } 4\end{array}$ \\
\hline Goldberger, $1991^{23}$ & Silicone rod & 10 & 12 & 24 & $\begin{array}{l}\text { Exposure keratopathy, } 1 \\
\text { Skin bulging over silicone rods, } 1\end{array}$ \\
\hline $\begin{array}{l}\text { Leone et al, } 1981^{24} \\
\text { Monofilament }\end{array}$ & Silicone rod & 15 & 20 & - & Infection, 1 \\
\hline Wasserman, $2001^{28}$ & Monofilament Nylon & - & 13 & 24 & $\begin{array}{l}\text { Recurrence, } 9 \\
\text { Infection/granuloma, } 1\end{array}$ \\
\hline Manners, $1994^{20}$ & Polypropylene & 9 & 10 & 18.7 & Recurrence, 5 \\
\hline $\begin{array}{l}\text { Wasserman, } 2001^{28} \\
\text { ePTFE (Gore-Tex) }\end{array}$ & Polypropylene & - & 8 & 24 & Recurrence, 3 \\
\hline Wasserman, $2001^{28}$ & ePTFE & - & 11 & 6 & Infection/granuloma, 5 \\
\hline $\begin{array}{l}\text { Steinkogler, } 1993^{19} \\
\text { Stored fascia lata }\end{array}$ & ePTFE & 26 & 37 & 36 & Rejection, 1 \\
\hline Wasserman, $2001^{28}$ & $\begin{array}{l}\text { Banked, donor, } \\
\text { irradiated fascia lata }\end{array}$ & & 35 & 18 & Recurrence, 18 \\
\hline Esmaili, $1998^{26}$ & $\begin{array}{l}\text { Banked, donor, } \\
\text { irradiated fascia lata }\end{array}$ & 72 & 132 & 120 & $\begin{array}{l}\text { Infection/granuloma, } 2 \\
\text { Reaction to donor fascia lata, } 2\end{array}$ \\
\hline Mauriello, $1998^{27}$ & Cadaveric fascia lata & 27 & 36 & 44 & None \\
\hline \multicolumn{6}{|c|}{ Autogenous fascia lata } \\
\hline El-Toukhy, $2001^{13}$ & Fascia lata & 24 & 34 & 33.8 & $\begin{array}{l}\text { Infection, } 1 \\
\text { Hypertrophic leg scar, } 1\end{array}$ \\
\hline Wasserman, $2001^{28}$ & Fascia lata & - & 24 & 30 & $\begin{array}{l}\text { Recurrence, } 1 \\
\text { Infection/granuloma, } 2\end{array}$ \\
\hline Deenstra, $1996^{25}$ & Fascia lata & 81 & 119 & 54 (median) & Exposure keratopathy, 12 \\
\hline Kemp, $1986^{4}$ & Fascia lata & - & 99 & 30 & $\begin{array}{l}\text { Infection, } 1 \\
\text { Overcorrection, } 2 \\
\text { Slipped, } 2\end{array}$ \\
\hline
\end{tabular}

Table 3 Complications of frontalis suspension surgery with Mersilene mesh

\begin{tabular}{|c|c|c|c|c|}
\hline Author, year & No of patients & No of eyelids & Mean follow up (months) & Complications (infection/extrusion/granuloma) \\
\hline Kemp, $2001^{14}$ & 20 & 29 & 11 & Late extrusion, 1 \\
\hline El-Toukhy, $2001^{13}$ & 32 & 46 & 33.8 & 0 \\
\hline Wasserman, $2001^{28}$ & - & 11 & 8 & $\begin{array}{l}\text { Recurrence, } 3 \\
\text { Infection/granuloma, } 1\end{array}$ \\
\hline Mutlu, $1999^{12}$ & 52 & 79 & Unknown & $\begin{array}{l}\text { Granuloma, } 3 \\
\text { Extrusion, } 2\end{array}$ \\
\hline Yalaz, $1997^{11}$ & 15 & 19 & 50 & $\begin{array}{l}\text { Granuloma, } 3 \\
\text { Extrusion, } 2\end{array}$ \\
\hline Gabrieli, $1996^{10}$ & 14 & 20 & 18 & None recorded \\
\hline Can, $1969^{\circ}$ & 22 & 23 & 25 & Extrusion, 1 \\
\hline Hintschich, $1995^{8}$ & 54 & 76 & 20 (median) & $\begin{array}{l}\text { Infection, } 1 \\
\text { Extrusion, } 3\end{array}$ \\
\hline Elder, $1993^{7}$ & 13 & 17 & 13.8 & $\begin{array}{l}\text { Granuloma, } 8 \\
\text { Localised discharge, } 1 \\
\text { Migration, } 1\end{array}$ \\
\hline Downes, $1990^{6}$ & 15 & 23 & 15 & Preseptal cellulites, 1 \\
\hline Downes, $1989^{5}$ & 11 & 17 & 10 weeks & Preseptal cellulites, 1 \\
\hline
\end{tabular}

particularly if there is fibre exposure. Suturing the eyelid stab incisions with $8 / 0$ Vicryl did not prevent infection in $2 / 20$ $(10 \%)$ patients in this study. Our overall soft tissue complication rate was $20 \%$, higher than in other reported studies (table 3). Complications occurred within a month of surgery, suggesting foreign body reaction, ${ }^{12}$ or infective aetiology despite postoperative antimicrobial prophylaxis. It was felt that a piece of overly wide mesh had contributed to the mesh exposure in case 4.

Removal of the mesh may result in ptosis, especially as a long length of mesh is dissected out both from the eyelid and between the eyelid and brow. ${ }^{31}$

There is a trade-off between complications and effectiveness for non-autogenous frontalis suspension materials.
Prolene suture and silicone rod have low infection and extrusion rates but their functional effect may diminish with time. Mersilene mesh and Gore-Tex suture have more soft tissue complications but a good long term functional effect. Only Autogenous fascia lata has both low morbidity and is long term effectiveness.

Mersilene mesh is an alternative to autogenous fascia lata for frontalis suspension surgery as it gives similar good functional results. Being a synthetic material it carries the risk of potential infection, granuloma formation, and extrusion. We now prefer to use alternative non-autogenous materials such as Prolene 2.0 suture or autogenous fascia lata, recognising their advantages and disadvantages. 


\section{Authors' affiliations}

P Mehta, P Patel, J M Olver, Western Eye Hospital, Marylebone Road, London NW1 5YE, UK

This paper was presented at the inaugural meeting of the British Oculoplastic Surgery Society, Birmingham, UK, May 2001.

Correspondence to: Miss Jane M Olver, Oculoplastic Service, Western Eye Hospital, Marylebone Road, London NW1 5YE, UK; janeolver@aol.com

Accepted for publication 10 March 2003

\section{REFERENCES}

1 Mustarde JC. Repair and reconstruction in the orbital region, 2nd ed. Edinburgh: Churchill Livingstone, 1980:325-8.

2 Beard C. Ptosis, 3rd ed. St Louis: CV Mosby, 1981:169-73.

3 Fox SA. Congenital ptosis. II Frontalis sling. J Paediatr Ophthalmol 1966:3:25-28

4 Kemp EG, James CR, Collin JRO. Brow suspension in the management of ptosis: an analysis of over 100 cases. Trans Ophthalmol Soc UK 1986; 105:84-7.

5 Downes RN, Collin JRO. The Mersilene mesh sling-a new concept in ptosis surgery. Br J Ophthalmol 1989:73:498-501.

6 Downes RN, Collin JRO. The Mersilene mesh ptosis sling. Eye 1990:4:456-63.

7 Elder MJ. Mersilene mesh and fascia lata in brow suspension: a comparative study. Ophthalmic Surg 1993;24:105-8.

8 Hintschich CR, Zurcher M, Collin JRO. Mersilene mesh brow suspension: efficiency and complications. Br J Ophthalmol 1995;79:358-61.

9 Can I, Can B, Yarangumeli A, et al. Ptosis surgery using Mersilene mesh suspensory material. Eur J Ophthalmol 1996;6:150-4.

10 Gabrieli CB, Recupero SM, Contestabile MT, et al. Fox's modified technique using the Mersilene mesh sling in the management of ptosis. Ophthalmic Surg Lasers 1996;27:924-8.

11 Yalaz M, Demircan N, Yagmur M, et al. Mersilene mesh: long-term results in oculoplastic surgery. Orbit 1997; 16:217-23.

12 Mutlu FM, Tuncer K, Can C. Extrusion and granuloma formation with Mersilene mesh brow suspension. Ophthalmic Surg Lasers 1999;30:47-51.

13 El-Toukhy E, Salaem M, El-Shewy T, et al. Mersilene mesh sling as an alternative to autogenous fascia lata in the management of ptosis. Eye $2001 ; 15: 178-82$
14 Kemp EG, MacAndie K. Mersilene mesh as an alternative to autogenous fascia lata in brow suspension. Ophthal Plastic Reconstruct Surg 2001;17:419-22.

15 Small RG. Frontalis sling for congenital ptosis. In: Levine MR, ed. Manual of oculoplastic surgery, 2nd ed. Boston: Butterworth-Heinemann, 1996:83-8.

16 Bodian M. Repair of ptosis using human sclera. Am J Ophthalmol 1968;65:352-8.

17 Broughton WL, Mathews IIJG, Harris DJ. Results of treatment using lyophilised fascia lata for frontalis suspension. Ophthalmology 1982;89:1261-6.

18 Tillet CW, Tillet GM. Silicone sling in the correction of ptosis. Am J Ophthalmol 1966;62:521-3.

19 Steinkogler FJ, Kuchar A, Huber E, et al. Gore-Tex soft-tissue patch frontalis suspension technique in congenital ptosis and in blepharophimosis-ptosis syndrome. Plastic Reconstruct Surg 1993;92:1057-60.

20 Manners RM, Tyers AG, Morris RJ. The use of Prolene as a temporary suspensory material for brow suspension in young children. Eye 1994;8(Pt 3):346-8.

21 Katowitz JA. Frontalis suspension in congenital ptosis using a polyfilament, cable-type suture. Arch Ophthalmol 1979;97:1659-63.

22 Carter SR, Meecham WJ, Seiff SR. Silicone frontalis slings for the correction of blepharoptosis: indications and efficacy. Ophthalmology 1996; 103:623-30.

23 Goldberger S, Conn H, Lemor M. Double rhomboid silicone rod frontalis suspension. Ophthal Plastic Reconstruct Surg 1991;7:48-53.

24 Leone CR, Shore JW, Van Gemert JV. Silicone rod frontalis sling for the correction of blepharoptosis. Ophthalmic Surg 1981;12:881-7.

25 Deenstra W, Melis P, Kon M, et al. Correction of severe blepharoptosis. Ann Plastic Surg 1996;36:348-53.

26 Esmaeli B, Chung H, Pashby RC. Long-term results of frontalis suspension using irradiated, banked fascia lata. Ophthal Plastic Reconstruct Surg 1998; 14:159-63.

27 Mauriello JA, Abdelsalam A. Effectiveness of homologous cadaveric fascia lata and role of suture fixation to tarsus in frontalis suspension. Ophthal Plastic Reconstruct Surg 1998; 14:99-104.

28 Wasserman BN, Sprunger DT, Helveston EM. comparison of materials used in frontalis suspension. Arch Ophthalmol 2001;119:687-91.

29 Fenton S, Kemp E. A review of the outcome of upper lid lowering for eyelid retraction and complications of spacers at a single unit over 5 years. Orbit 2002;21:289-94.

30 Peyman GA, Koziol J, Janevicins R. Intraocular lens fixation with Dacron mesh: part II. Ophthalmic Surg 1977;8:87-93.

31 Mehta P, Patel P, Olver JM. Management of Mersilene mesh chronic eyelid complications - a systematic approach. Eye (in press). 